\title{
Doctors of 1776-I*
}

\author{
J D SPILLANE
}

British Medical fournal, 1976, 1, 1571-1574

It was hot and humid in Philadelphia in July 1776. Horseflies tormented the members of the Continental Congress as they met daily in the Statehouse where, all that year, pressure had been mounting in favour of independence. The city was one of some 38000 people, larger than Bristol or Dublin, the second largest city in the English-speaking world. Only London was larger. ${ }^{1}$ The population of the 13 colonies was about 3000000 , and of the 3500 physicians no more than 400 of them held a degree of $M B$ or $M D$ and only 50 had graduated from the two American schools in Philadelphia and New York. ${ }^{2}$ Earlier in the year the publication of Tom Paine's pamphlet Common Sense had exercised a stirring effect, encouraging the doubters, rallying the moderates, and explaining that liberty was not derived from the British constitution but was a right of all mankind. In Philadelphia, where it was printed, "It has fretted some folks here more than a little." 3 Rumours that German troops were among those arriving to invade the colonies of King George III stunned many and helped to cast the die. Then, on 1 July, news reached Congress that General Howe's invasion force had been sighted off New York: "a stupendous flotilla . . . bigger than the Armada." + The delegates had to decide how to meet this threat.

There were the New England colonies (Maine, New Hampshire, Vermont, Connecticut, and Massachusetts); the middle colonies (New York, New Jersey, Maryland, and Rhode Island); and the southern colonies (Virginia, the Carolinas, and Georgia).

* Based on the Harveian Lecture of 1976 delivered to the Harveian Society of London in March 1976.

$\dagger 130$ sail were sighted (about the number in the Spanish Armada fleet) but in fact there were 52 large war vessels, 24 armed sloops, and 400 transports.

Dartmouth Medical School, Hanover, New Hampshire, USA

J D SPILLANE, MD, FRCP, Sandoz Foundation visiting professor of neurology (present address: Prescelly, Newport, Dyfed, Wales)
There was no limit to the number of delegates which a colony could send to Congress, but each colony counted for only one vote. Views had varied widely on political, sectional, and religious grounds. Unanimity was not achieved without a long struggle. But in the end, the story has it that the president, John Hancock, said, "We must all hang together," to which Benjamin Franklin replied, "Assuredly we must for if we don't we'll all hang separately." And so it was done.

Thomas Jefferson, the young lawyer from Virginia, was instructed to prepare a document (fig 1). He did so, writing it across his knees on a portable desk that he had designed and scorning quotations, saying it was not his function to be a mouthpiece for Aristotle and others. It was examined by a committee and after certain alterations had been made, it was finally presented to Congress on 2 July, when the "lobster-backs" (you know who) were streaming ashore at Staten Island. The next two days were spent in editing it. On 4 July it was approved. It was entitled "The Unanimous Declaration of the Thirteen United States of America." Off it went to the printers and thence was transmitted throughout the land, where there were bonfires, bellringing, and a great deal of "huzzaing." On 8 July it was read aloud at the Statehouse in Philadelphia (fig 2) and the King's arms were torn down at the entrance and tossed that night on to a bonfire.

By custom the roll call of delegates when voting was from north to south. Thus it came about that the first person to vote for the Declaration was a physician. He was Josiah Bartlett, aged 47, from Kingston, New Hampshire, the senior delegate from that State. Similarly, when the parchment copy of the Declaration was made and signed (fig 3) on 2 August his name went first after that of the President. The last of the 56 signatories was also a physician, Dr Lyman Hall of Georgia. In all five doctors' signatures were appended to the document. The most famous is Dr Benjamin Rush of Philadelphia. The others were Matthew Thornton of New Hampshire and Oliver Wolcott of Connecticut.

More than half of those who signed were laywers, though not necessarily practising, law being a traditional form of education 
a Dularation in the Representatives of the WWTED STATES
OF AMERICA, in Gemeral Congress ausembled.

When in the course of haman events it hecomesnecesary for ta preogle to divolve the politifal hands which have comecte them with another, and to

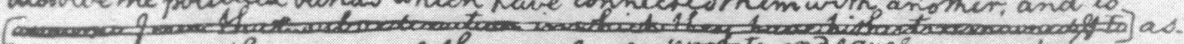

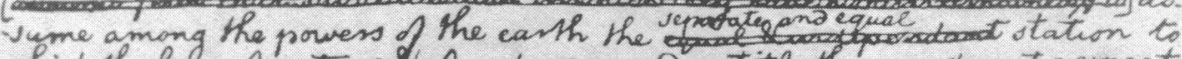
Wich the laws of nature \& of nature's gov entitle them. a decent respect to the opinions of mankins requires that they nowed declare the caused Which impel them to the edfequre vepanation We hald these hutho to be sepanation

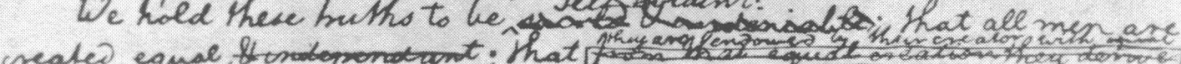

FIG 1-Facsimile of original draft by Jefferson of Declaration of Independence.

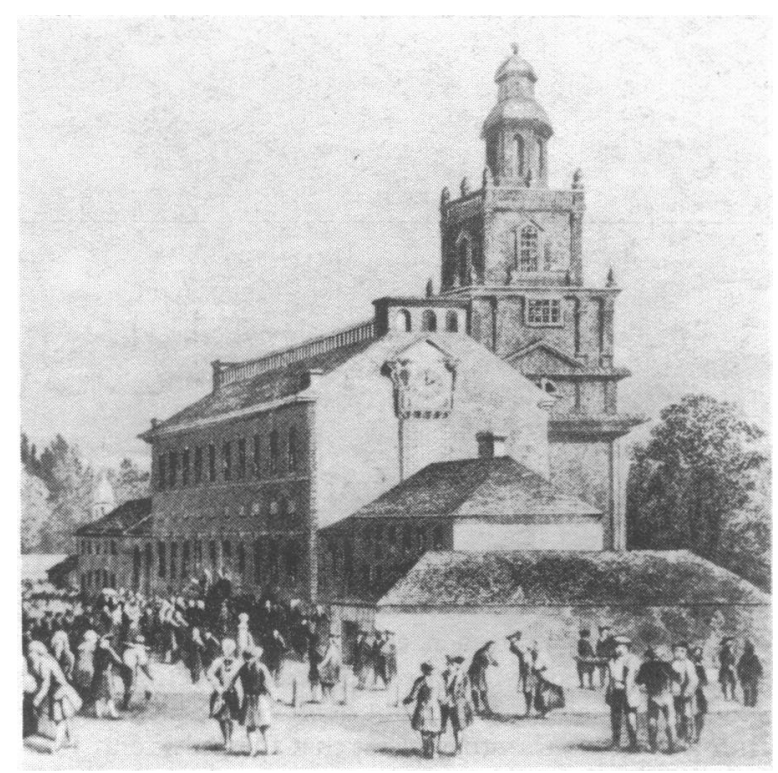

FIg 2-Old State House, Philadelphia.
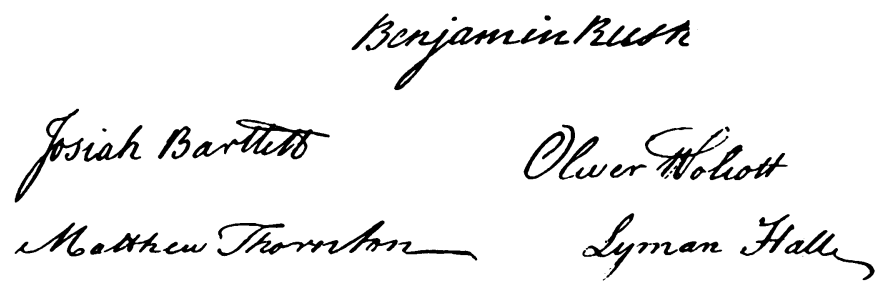

FIG 3-Signatures of five doctors who signed the Declaration of Independence.

among the upper classes. There were two clergymen. Most were born in the colonies of British ancestry. A few were born abroad: one in Wales, two in England, two in Scotland, and three in Ireland. ${ }^{1}$ There was no coloured person, no Jew, and one Catholic.

War with England had broken out a year before, and in a military hospital in Cambridge, outside Boston, was a 22-yearold surgeon's mate (assistant surgeon), James Thacher (17541844), whose diary and writings subsequently furnished medical historians with valuable documentation, and three are classics of American medical history. His first important book, in 1817, was entitled American Modern Practice or a Simple Method of Prevention and Cure of Diseases. His war diary, A Military fournal during the American Revolutionary War, was published in 1823. In 1828 came his American Medical Biography (fig 4), which contains the biographies of 168 physicians. In his preface Thacher wrote: "It is a delightful employment to portray the

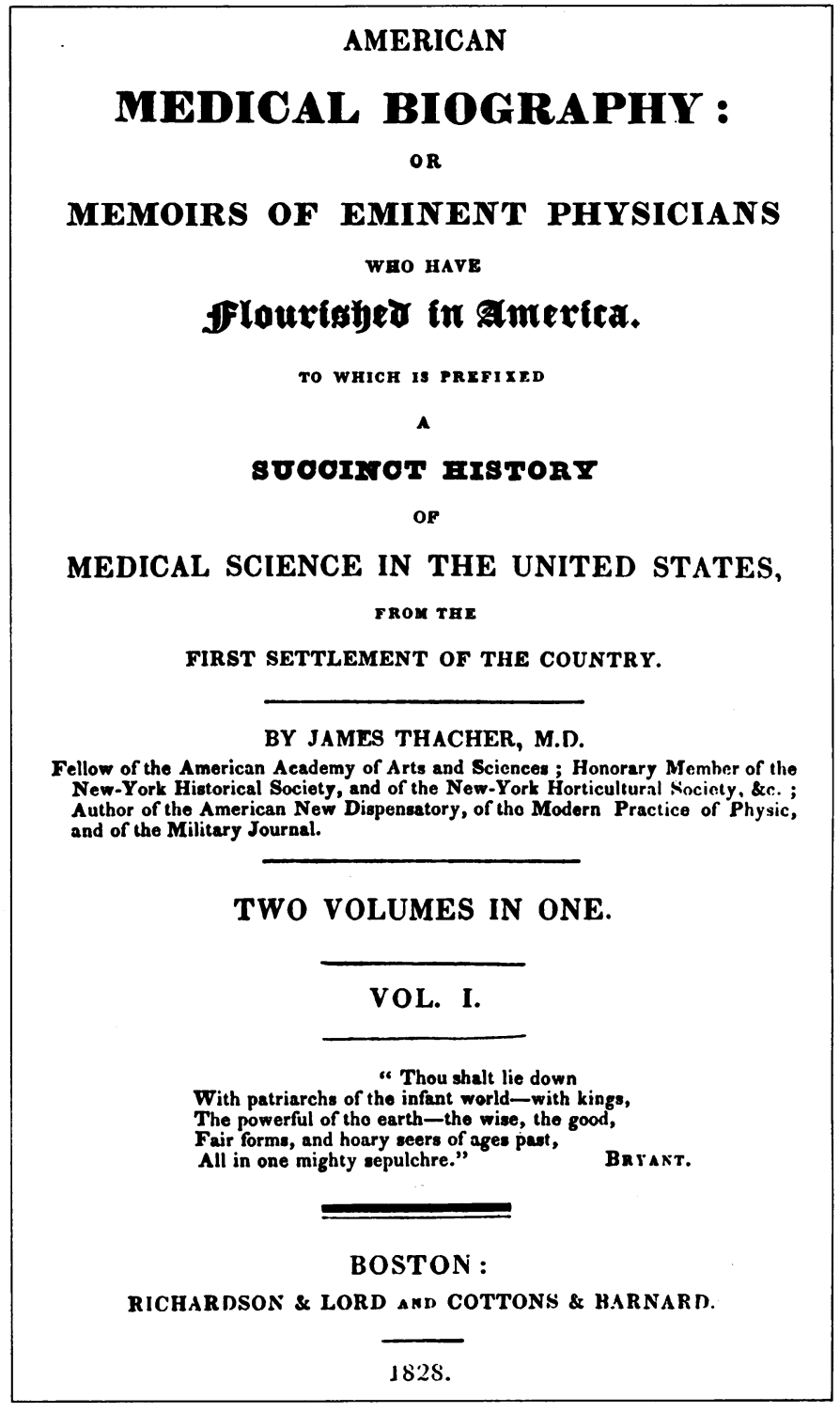

FIG 4-Title page of Thacher's Medical Biography.

varied shades of the human character as exhibited on the great theatre of the world; to contemplate in what manner men have lived, and how they have died."

Benjamin Rush, Josiah Bartlett, and Matthew Thornton figure in Thacher's diary and biography but he also records the activities of many other medical men of 1776. In general the lives are eulogistic, written in high-flown prose, full of pious sentiments and rolling patriotic phrases, but interspersed with fascinating vignettes and intriguing allusions and references, vivid and immensely readable. 


\section{Dr Benjamin Rush (1746-1813)}

"The Father of American Medicine," "the American Sydenham," "the Hippocrates of Pennsylvania" was born in Philadelphia of English Quaker stock in 1746..$^{4-15}$ Benjamin Rush (fig 5) was descended from John Rush, yeoman dissenter from Oxfordshire, a captain under Oliver Cromwell, who settled in Philadelphia in 1683. Benjamin graduated at Princeton in 1760 and, deciding on a medical career, was apprenticed to Dr John Redman, a physician who enjoyed a large practice in the city of Philadelphia. His pupils were given the works of Boerhaave, van Swieten, and Sydenham to read. Rush learnt his Hippocrates by translating his aphorisms into English. Later he translated the works of Sydenham. In 1776 he journeyed to Edinburgh, like so many young American doctors of the day who could afford it, and in 1768 graduated MD there. He thus came under the influence of Cullen and Monro secundus, and in London he met Lettsom, William Hunter, Fothergill, Samuel Johnson, Oliver Goldsmith, and Sir Joshua Reynolds. He travelled to Paris and met the Abbé Nollet, experimenter with static electricity and coiner of the term "the Leyden Jar."

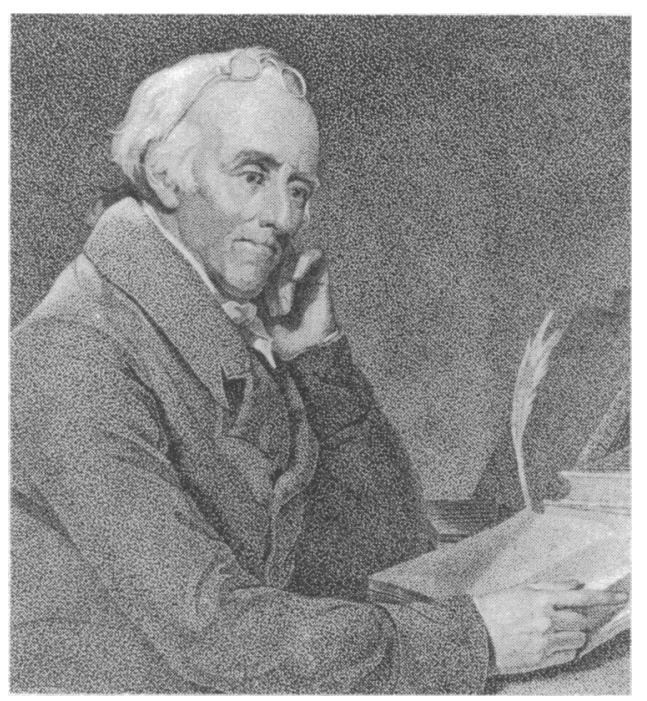

FIG 5-Dr Benjamin Rush.

Returning to Philadelphia in 1769 , he took up practice and was appointed professor of chemistry in the medical school. This was the first in the country and had been started by Drs William Shippen and John Morgan in 1765.

During the war years Rush served in Congress and also as a surgeon-general in the newly created medical ("hospital") department of the army. He attended the fatally wounded Dr Hugh Mercer at the battle of Princeton on 3 January 1777. Mercer had been an assistant surgeon to Prince Charles Edward at Culloden in 1745. He had fled to Virginia and settled there, becoming a friend of Washington.

Thacher's biography of Rush comprised 40 pages and is entirely laudatory. In a letter to Thacher, Rush said, "Medicine is my wife, science is my mistress, books are my companion, my study is my grave." Rush kept a notebook with two sections, one for facts and one for ideas, a habit which no modern reader of Rush would suspect, so jumbled and nonsensical were so many of his thoughts and observations. He must have been a compulsive writer; "Ideas," he said, "whether acquired from books or by reflection, produce a plethora of the mind, which can only be relieved by depletion from the pen and tongue."

As in the American Civil War, the creation of a medical military department brought confusion and jealousy. Dr Benjamin Church, eminent Boston physician, was appointed the first director-general. But he was found to be in "treasonable communication" with the enemy and was arrested, courtmartialled, and found guilty. After a year in prison he was released and allowed to sail with his family for the West Indies. They were heard of no more and their ship was presumed lost. Dr John Morgan of Philadelphia was next appointed but he could not win the co-operation of the regimental surgeons nor obtain sufficient authority from Congress to initiate obvious reforms. He was eventually dismissed and replaced by his rival Shippen. Morgan subsequently vindicated himself with Congress and eventually succeeded in having Shippen himself courtmartialled for "malpractice and misconduct in office." The verdict was equivocal and Shippen was able to continue army service in a "voluntary" role. Rush assisted Morgan in his fight with Shippen. It is difficult to imagine these three together on the staff of their medical school after the war. As a matter of fact, poor Morgan-whose wealth, looks, brains, and European education had promised fame-eventually died a recluse. Both he and Shippen were attended by Rush in their final hours.

Rush, a pugnacious dogmatic character, had no great influence in Congress. "There," he remarked on hearing that Jefferson dipped his feet in cold water on rising, "the bowels sympathise with the feet above any other external part of the body and suffer in a peculiar manner from the effects of cold upon them.", 3 When he was President Jefferson had something to say about 18 th century medical theorists. He said that patients sometimes got "well in spite of medicine"16 and that "the adventurous physician ... substitutes presumption for knowledge. From the scanty field of what is known, he launches into the boundless region of what is unknown." 17

Rush pronounced on many topics-hygiene, tobacco, alcohol, capital punishment, the education of women, and slavery. In 1778 he published a book on military hygiene, Directions for Preserving the Health of Soldiers. In 1794 came his celebrated account of the devastating epidemic of yellow fever in Philadelphia entitled An Account of the Bilious Remitting Fever. His terrible therapeutic ritual of bleeding and purging for this disease was opposed at the time and has been condemned ever since. The Englishman and radical journalist William Cobbett was in Philadelphia, and in his journal, the Porcupine's Gazette, he castigated Rush and hurled at him such scurrilous invective that Rush had to leave town. Ultimately he won a libel suit against Cobbett. Of bleeding, Cobbett said, "the patients accustom themselves to live without blood, but the moment the process is completed they expire."10 Washington himself, on his death bed in 1799, was subjected to repeated purging, bleeding, and blistering. Rush must have killed many patients: his confidence, fanaticism, and energy assumed extraordinary, possibly pathological proportions. But Thacher thought "It is probable that no less than 6000 . . . were saved by bleeding and purging." Rush saw 100 patients daily. "Had the same events taken place in the early ages of the Pagan world," wrote Thacher, "he would have been deified; if in the dark ages of the Christian era, he would have been canonised and worshipped as a saint." It is difficult to reconcile these words of Thacher with those he wrote in his Practise of Medicine: "A physician ... should not allow his mind to be enslaved by systems, nor to imbibe bigotted attachment to great names."

And yet, such were Rush's talents for speculation and fantasy, he was able to write in an article entitled "On the Causes of Death in Diseases that are not Incurable" that there were three causes. The first derived from ignorance, negligence, and preference of reputation, etc, on the part of the physician; the second from ignorance, prejudice, or neglect on the part of the patient; and the third from similar faults by visitors and attendants. ${ }^{18}$ And of John Hunter he felt he could say "He never gave up anything he had once asserted till he gave up the ghost." Thacher thought "It was not so with Rush." The concepts of Cullen and Brown which Rush originally taught were gradually replaced by a grander one of his own design-one which was "A more simple and consistent system of medicine than the world had yet seen." "19 Ultimately he considered that "There is 
but one disease in the world. The proximate cause of disease is irregular, convulsive, or wrong action in the system affected.":-20

But just as Cotton Mather, FRS, could condemn witches in Salem yet advocate and introduce variolation for smallpox in Boston, so also could the blood-letting metaphysician Benjamin Rush advocate a humanistic approach to the study and care of the insane. He arranged for a special wing to be built for them in the Pennsylvania hospital in 1796 and he advocated forms of occupational therapy. But cold baths, bleeding, and purging were not forgotten and he devised and had constructed a special, restraining chair, into which a patient could be fastened. He had the audacity to call it a "tranquilliser" (fig 6).

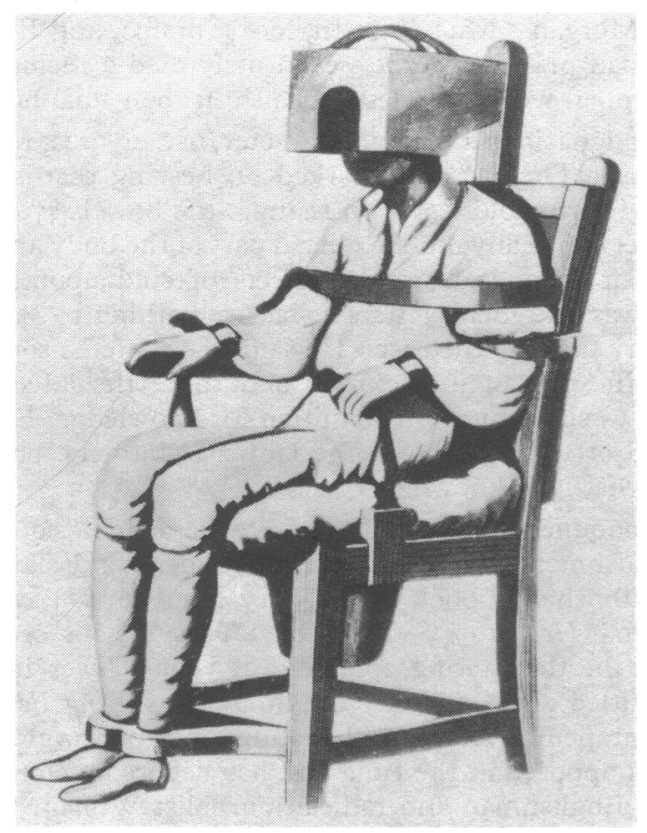

FIG 6-Rush's "tranquilliser."

A year before he died Rush published his Medical Inquiries and Observations upon the Diseases of the Mind, which has earned him yet another title- "father of American psychiatry.":21 It has often been said, not quite truly according to Shryock, ${ }^{16}$ that Rush's book remained the only American one on insanity until Hammond's treatise in 1883.22 Rush viewed insanity as a disease of the brain due to alterations in its blood vessels, and there were two main groups. In hypochrondriacal states there was partial intellectual derangement; in euphoric states there was general intellectual change. Blood supply to the insane brain was reduced by whirling the patients around in a machine of his own devising, called a "gyrator." Nevertheless, Tuke"3 thought that Rush "saw so far in advance of the age in which he lived." Although there was good in Rush's idea that behavioural as well as intellectual abnormalities should be viewed as disorders of the brain, his medical contributions were never deserving of the grandiloquent titles some have bestowed on him. American medicine deserves a better father figure than Benjamin Rush. Indeed, says Shryock, ${ }^{16}$ the male parent of American somatic medicine has never been clearly identified."

The continuing and extraordinary differences of opinion about the medical reputation of Rush over two centuries has been reviewed by Shryock. ${ }^{16}$ Two of the many interesting examples he mentions may be cited. Oliver Wendell Holmes (a Bostonian) said that Rush "Could not help feeling that Nature had been a good deal shaken by the Declaration of Independence, and that American [medical] art was getting to be rather too much for her-especially as illustrated in his own practise" (shades of Sir Francis Walshe!). Silas Weir Mitchell (a Philadelphian), on the other hand, thought Rush was "the greatest physician this country has produced."

\section{Dr Josiah Bartlett (1729-95)}

Josiah Bartlett was born in Amesbury, Massachusetts, and at 16 was apprenticed to a Dr Ordway, "but he soon exhausted the doctor's scanty library and resorted to others for a supply." In 1750 , when 21 , he set up his practice in Kingston, New Hampshire, "having completed his medical education." In due course he became a magistrate, a member of the provincial legislature, a colonel in the regimental militia, and, in 1775, a member of the Continental Congress. "When the vote for American Independence was taken Colonel Bartlett's name was first called and he boldly answered in the affirmative." He was consequently the "first, after the President, to sign that memorable instrument." He became the first Governor of the State of New Hampshire in 1793, dying in 1795, aged 65. It was said of him in the interment sermon that his "judgment was sound and prospective; his natural temper was open; he was humane and considerate."

\section{Dr Matthew Thornton (1714-1803)}

Born in Ireland, Matthew Thornton came with his father to Connecticut, and after "an academical and medical education", started to practise in Londonderry, New Hampshire. He became a justice of the peace and a "Colonel of Militia under the Royal Government but when the political crisis arrived, when the government in America was dissolved, Colonel Thornton abjured the British interest and with a patriotic spirit adhered to the glorious cause of liberty." He was elected to the Continental Congress in 1776 and "his signature stands among the fifty-six worthies who have immortalised their names by that memorable act." Thornton became a judge of the Superior Court of New Hampshire and in 1780 "purchased a farm on the banks of the Merrimac, near Exeter." In his eighties he remained "versatile and full of anecdote," writing "political essays for the newspapers," and a "metaphysical work called 'Paradise Lost,' which was not published but those with access to the manuscript pronounced it a very singular production." He lived to be 89 and was "honoured in his day and generation."

Thacher did not include in his Biography (which was published by subscription) the other two medical signers of the Declaration-Oliver Wolcott of Connecticut, and Lyman Hall of Georgia-but we know that they both became Governors of their States.

In his diary and biography Thacher mentioned many other medical men (see part II).

The list of references will be given at the end of part II.

What are the differences between proximal vagotomy, truncal vagotomy, selective vagotomy, and highly selective vagotomy?

Truncal vagotomy is an operation in which the two main trunks of the abdominal vagus (anterior and posterior) are divided-usually at the level of the diaphragm. Selective vagotomy means division of the gastric vagus with preservation of the hepatic and coeliac branches. Thus the stomach is denervated but the gall bladder and small bowel have their nerve supply retained. Proximal or highly selective vagotomy is an operation in which the branches of the vagus to the acid-secreting portion of the stomach are divided close to the lesser curvature. The hepatic and coeliac branches remain intact, and the anterior and posterior nerves to the antrum (nerves of Latarjet) are preserved. This reduces acid secretion but the function of the antrum and pylorus is normal. In truncal and selective vagotomy a "drainage operation" (pyloroplasty or gastroenterostomy) is needed to allow the stomach to empty. In proximal vagotomy no drainage operation is required. 